\title{
A LOW ENERGY COMMUNITY? A comparative study of Eco-Villages around the world
}

\author{
Nilesh Bakshi \\ Victoria University of Wellington
}

Prof Robert Vale

Prof Brenda Vale

\begin{abstract}
This paper investigates what is being done to produce sustainable community developments to minimize ecological footprint. Five international case studies were compared with the Govardhan Eco Village in Maharashtra, India. The study describes each case study and then looks at how various sustainable principles have been integrated into the community. Each case study was compared to an appropriate set of sustainability indicators to see which parameters were addressed. In order to establish the fundamental sustainable design focus of each case study, whether technology or human behaviour, the analysis looked at the types of parameters governing each project. Results showed the parameters incorporated in the case studies did not obviously change with time. Further scrutiny of the parameter matrix for all case studies suggested two distinctly different trends in the 'eastern' and 'western' examples. The Indian example appears to show true sustainable development, relying less on technology and more on human capital.
\end{abstract}

\section{INTRODUCTION}

As identified by Holling (2000) and substantiated by Ewing and Moore (2010) there is growing awareness of the massive changes that human societies are causing to the environment, implying a need for a fundamental change in lifestyles (Holling 2000). In 1987 the Brundtland Report, Our Common Future, first defined Sustainable Development as human development that "meets the needs of the present without compromising the ability of future generations to meet their own needs" (United Nations General Assembly, 1987) and supported policies such as the adoption of the Kyoto Protocol; the founding of Agenda 21 (agenda for the 21st century) in 1992; and the 1997 formation of the Global Reporting Initiative (GRI). A more recent populist influence was the film, An Inconvenient Truth, by former American Vice President Al Gore (Gore, 2006). Most energy consumption and pollution originates in the lifestyles of the citizens of developed countries (Mithraratne, 2013) and this has caused some members of the architectural profession to rethink design principles, resulting in new 'sustainable' developments, as discussed here. The 1992 Earth Summit in Rio de Janeiro led the way by outlining a set of actions for sustainable development, Agenda 21(United Nations Environment Programme, 1992). To implement this, the United Nations instituted a "set of indicators of sustainable development" to monitor progress (Bell and Morse 2008).

Robert Vale \& Brenda Vale are professors in the School of Architecture, Victoria University of Wellington, New Zealand. Nilesh Bakshi is a $\mathrm{PhD}$ candidate in the School of Architecture, Victoria University of Wellington, New Zealand. 


\section{PROBLEM STATEMENT AND OBJECTIVES}

Reducing energy use in new and existing buildings is an urgent necessity. Energy consumption in the building sector is more than one-third of national energy use in India (CARBSE 2014), and with further growth in this sector, India, along with other developing countries, faces a formidable challenge in reducing its dependence on fossil fuels. Biocapacity, referred to as the new wealth of nations (Ewing and Moore, 2010), is the ability of ecosystems to provide the resources people need and absorb the wastes they create. At 58.2 million global hectares (gha), New Zealand has the world's largest biocapacity, and uses only $39.4 \%$ of it. With an ecological footprint of 22.9 million gha (Ewing and Moore, 2010), New Zealand is also unhappily responsible for one of the world's larger ecological footprints of 5.17 gha per person (shown in figure 1). As shown in figure 1 the global 'fair share' footprint, which all people could have without overtaxing resources, is 1.7 gha per person as opposed to the average of 2.7 the world is using currently, made possible by using finite resources such as coal, oil and uranium (WWF, 2010). Should India, whose biocapacity is 630 million gha and whose ecological footprint is only 0.9 gha per person, (Global Footprint Atlas 2014) be following the example of countries like New Zealand, which take far more than their fair share of the Earth's resources?

This study is a comparison of current sustainable design practice in India and the developed world to identify if, and how, India might learn from the successes and failures of 'developed' countries. The aim is not only to determine how varying nations identify and assess sustainable design but also whether there has been a shift in focus in sustainable developments. The best example of a sustainable development in India (Govardhan Eco Village) will be compared with similar privately funded examples from New Zealand (Earthsong), Germany (Solarsiedlung), the United Kingdom (BedZED), Japan (Fuji Eco-park Village), and Australia (Crystal Waters), countries which have roughly similar ecological footprints, all well above the fair share (Figure 1).

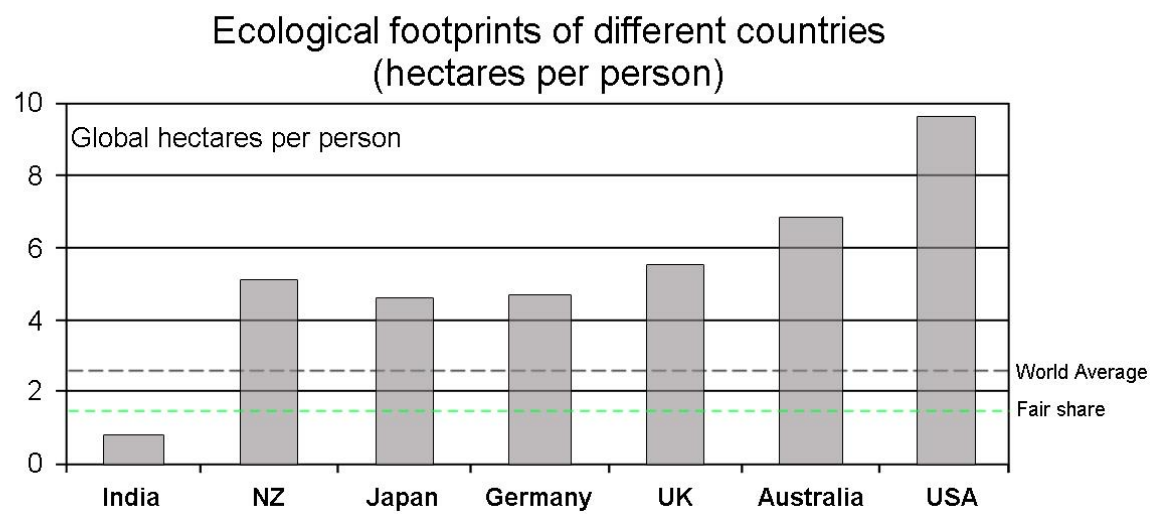

Figure 1 Case study selection based on footprint (USA included for comparison only). Source: Global footprint network (2010)

The developments were selected based on self-reported claims of sustainability that purport to follow guidelines determined by Agenda 21 (United Nations Environment Programme, 1992) as discussed by Bell and Morse (2008) and by Bakshi (2009).

\section{CASE STUDIES}

Table 1 identifies the self-reported case study parameters ordered by their occurrence in the six developments to give an overview of the sustainable design emphasis in each case. 
Table 1: Parameters in occurrence order

\begin{tabular}{|c|c|c|c|c|c|c|}
\hline & New Zealand & Germany & Australia & Japan & UK & India \\
\hline & Earthsong & Solarsiedlung & Crystal Waters & Fuji Eco-Park & BedZED & Govardhan \\
\hline Waste water recycling. & $\checkmark$ & $\checkmark$ & $\checkmark$ & $\checkmark$ & $\checkmark$ & $\checkmark$ \\
\hline Renewable source of energy & & $\checkmark$ & $\checkmark$ & $\checkmark$ & $\checkmark$ & $\checkmark$ \\
\hline Low energy lighting & $\checkmark$ & $\checkmark$ & $\checkmark$ & $\checkmark$ & $\checkmark$ & \\
\hline Passive solar design & $\checkmark$ & $\checkmark$ & $\checkmark$ & $\checkmark$ & $\checkmark$ & \\
\hline Efficient recycling and segregation & 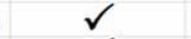 & $\checkmark$ & $\checkmark$ & $\sqrt{ }$ & & $\checkmark$ \\
\hline Rain water collection & $\checkmark$ & $\checkmark$ & $\checkmark$ & $\checkmark$ & & \\
\hline Local work availability & $\checkmark$ & $\checkmark$ & $\checkmark$ & & & $\checkmark$ \\
\hline Proximity to public transport & $\mathbf{v}$ & $\checkmark$ & & $\checkmark$ & & 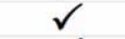 \\
\hline Environmentally friendly materials & $\checkmark$ & & $\checkmark$ & & & $\mathbf{v}$ \\
\hline Energy efficient appliances & & $\checkmark$ & & $\checkmark$ & $\checkmark$ & \\
\hline On site sewage treatment & $\checkmark$ & & & & $\checkmark$ & $v$ \\
\hline Farming & & & $\checkmark$ & $\checkmark$ & & $\checkmark$ \\
\hline Permaculture design & $\checkmark$ & & $\checkmark$ & $\checkmark$ & & \\
\hline Facilitates changing demographic & $\checkmark$ & $\checkmark$ & & & & \\
\hline CHP system & & $\checkmark$ & & & $\checkmark$ & \\
\hline Sustainable behaviour education & & & & $\checkmark$ & & $\checkmark$ \\
\hline Self sustained food sources & & & & $\checkmark$ & & $\checkmark$ \\
\hline Preserving local ecosystems & & & & $\checkmark$ & & $\checkmark$ \\
\hline Energy Plus design & & $\checkmark$ & & & & \\
\hline Balance of hydrology & & & $\checkmark$ & & & \\
\hline Site restoration/reforestation & & & $\checkmark$ & & & \\
\hline
\end{tabular}

\section{Case study one: Earthsong Eco-Neighborhood, New Zealand (2008)}

Earthsong is based on the three principal areas of sustainable design (Environmental, Social and Economic) as established in 'Agenda 21', (Bell and Morse, 2008). Environmental consideration at Earthsong relates to the overall design of buildings and landscape into a coherent whole; orientation of all buildings on principles of passive solar design and natural climate control; building materials choice considering embodied energy, durability, toxicity, recyclability and environmental impact; collection and re-use of rainwater and waste water; renewable energy; solar hot water systems; and clustering of buildings creating productive open spaces (Earthsong 2014). The 'village' arrangement balances the needs of individuals and community. Physical spaces encourage a diverse range of social interaction; cars are confined to the outer regions of the site; varying dwelling sizes support a wide range of ages and household types; a centrally located common house is a focus for community activities; and resident management occurs through the body-corporate. A self-sustaining economy to allow creation of on-site work and wealth was achieved through shared workshop and office facilities; leasable multi-purpose workspaces (stage 2); reduced domestic energy costs from energy efficient and passive solar design; reduced commuting costs through the site being 500 metres from a railway station.

The Earthsong Eco-Neighborhood's incorporation of some onsite renewable energy and permaculture makes it a more sustainable co-housing project. Sustainable materials were also considered important, with careful management of non-renewable resources. As stated (Earthsong Econeighbourhood 1999) this required;

- Specifying sustainably grown timbers as an integral part of each building;

- Using coating systems/carpets/thermal insulation with reduced environmental impact;

- Incorporating some major recycled building products.

- Encouraging better management of water as a precious resource through rainwater harvesting and having water efficient devices and grey-water recycling.

\section{Case study two: Solarsiedlung (The Solar Village), Germany (2008)}

Solarsiedlung $\mathrm{GmbH}$ is a sustainable scheme that incorporates 'energy-plus' initiatives to produce more energy than it consumes (EEG, as of 1st April 2000). Apart from terraced housing it has an office/housing block based on German Passivhaus and Plus Energy House directives. Environmental consideration comes from material selection, appliance choice, energy plus initiatives and limiting cars to the outskirts of the site. The scheme has four main elements (Behling \& Schindler 1996); 
1. Use of environmentally friendly materials (wood from regional forests, PVC-free, environmentally friendly insulation)

2. Highly insulated thermal building shell (heat requirement: $11-14 \mathrm{kWh} / \mathrm{m}^{2}$ per year)

3. Active ventilation with heat recovery

4. Photovoltaic panels on the roofs

The distance between buildings allows passive solar heating and solar electricity generation. Solar electricity is fed into the grid and extracted as needed. Any additional energy required in the winter is provided by a local wood-chip fuelled combined heat and power station (Solar Architecture 2014). Rainwater passes through a "biotope" for purification and to relieve pressure on local storm water drains, with the aim of recharging the city groundwater. Some rainwater is captured for garden irrigation and toilet flushing. The buildings have large south-facing glazed openings to maximize solar gain and small openings to the north to minimize heat loss. Vacuum insulation is used on opaque portions of the facade. Triple glazing reduces heat loss through windows and glazed facades (Behling \& Schindler 1996). Because this project produces more energy (from renewable sources) than it consumes it can be considered to be sustainable design.

\section{Case study three: Crystal Waters Eco-village, Australia (1988)}

In 1996, Crystal Waters in Australia received a United Nations World Habitat Award for its "pioneering work in demonstrating new ways of low impact, sustainable living" (Barton 2013). There were six design objectives at Crystal Waters:

1. Clean air, water and soil (thus food)

2. Freedom in spiritual belief

3. To work towards a guarantee of meaningful activity for all

4. To create a place for healthy play and safe recreation

5. Active social interaction

6. Healthy shelter

Crystal Waters accommodates up to 300 people with $80 \%$ of the land set aside for agriculture, and steeper areas given to forestry, recreation and natural habitat.The houses are built of a variety of materials such as straw bale, rammed earth, poles and mud domes, and avoid rainforest timbers and toxic chemicals. The EcoCentre (for education) has rammed earth walls, photovoltaic power, rainwater collection, and a biolytic waste system. The 83 residential lots are arranged in clusters to encourage interaction, co-operation and a sense of belonging. Scheme aspects show careful consideration for the environment, social needs and the economy. Food is grown onsite and most residents maintain home gardens and orchards. The scheme has 'home occupation' zoning, which creates business zones within the residential areas (Barton 2013). The permaculture design (Mollison and Slay 1994), which has a diversity of plants and wildlife uses knowledge of eco-systems to create a more sustainable way of life. The hydrological balance was maintained, ensuring the quality and quantity of the water downstream was not negatively affected by the development (Mollison and Slay 1994). Seventeen multi-purpose dams provide a flood mitigation strategy by absorbing runoff, with the overflow directed into the rivers via swales (Barton 2013). They are also a source of emergency water. A long term sustainable approach is taken to forestry. Trees were planted to provide habitat and moderate environmental extremes, as well as for various timber end uses. Buildings make extensive use of renewable materials with particular emphasis on passive solar design (Barton 2013).

\section{Case study four: Fuji Eco-park village, Japan (2000)}

Fuji Eco-park village is a project with a perfected "Permaculture Master Plan" (World Permaculture projects 2014). The project was scrutinized for its environmental and financial selfsufficiency; and its ability to be self-replicating and because it achieved all these it was included in a 
global list of sustainable permaculture projects (World Permaculture projects 2014). It was also recognized as an example of sustainable living in the Eco-village conference in Japan 2005 (GEN 2014). The Fuji Eco-park village is an eco-housing development with a single main dwelling, the Centre House, built on passive solar principles on 7.5 acres of land. Environmental consideration is given to transportation options, appliance choice, materials selection, energy consumption, and construction methods. The scheme has four main elements (Permaculture News 2014);

1. Renewable agriculture

2. Renewable energy

3. Sustainable design for the built environment

4. A water conservation scheme

The implementation of all four aspects makes this project unique. The layout is based on wind and solar orientation for renewable agriculture and renewable energy collection. There are solar PV panels and onsite wind generated electricity. The site layout has a main area for vegetables, an animal farm and a wind turbine farm. Because the scheme revolves around a single Centre House there was ample space for PV panels at ground level, making them easier to maintain. The wind farm and PV panels are said to produce more than enough energy for the single dwelling. To achieve renewable agriculture $90 \%$ of the land was devoted to food self-reliance (World Permaculture projects 2014). This led to the creation of a potato field, blueberry farm, pumpkin field, sweet corn field, herb gardens, earth worm farm, bee keeping farm, compost area and the orchard (Permaculture News 2014).

\section{Case study five: BedZED (Beddington Zero Energy Development), United Kingdom (2002)}

The BioRegional committee defines BedZED as the "UK's largest mixed use sustainable community" (Bio-regional 2009). It further states the scheme is one of the most successful projects to follow Agenda 21 in the United Kingdom. The project was aimed to be a zero energy design, only relying on energy from onsite renewable sources (Desai and Riddlestone 2002), and was designed to incorporate techniques to utilize resources sustainably. The three main principals of design were (Desai and Riddlestone 2002);

1. Zero fossil energy

2. Maximise passive solar energy

3. A "pedestrian first" policy

After its evaluation by the BioRegional committee (BioRegional 2009), the scheme was shown to be as not as successful in performance as intended. BedZED is the only one of the six case studies for which there is a detailed record of performance in practice. Identified in the report by BioRegional (2009), BedZED's design reduces space-heating requirements by $88 \%$, one of the major design features that was intended to contribute to this is the multicolored wind funnels that provided passive ventilation (BioRegional 2009), but these had been rendered inoperative by rust a few years after the building opened (Vale 2014). Hot-water consumption was 57\% less then the UK average; the electrical power used, at $3 \mathrm{kWh}$ per person per day, was $25 \%$ less than the UK average; $11 \%$ of this was produced by solar panels; mains-water consumption was reduced by $50 \%$; and the residents' car mileage is $65 \%$ less than the UK average. There are $777 \mathrm{~m}^{2}$ of solar PV panels. Tree waste was to fuel the development's cogeneration CHP plant to provide district heating and electricity, although this system is currently not working and electricity comes from the grid (BioRegional 2009). All dwellings face south to take advantage of solar gain, incorporate triple glazing, and have high thermal insulation (Desai and Riddlestone 2002). Rain water is collected and reused. Appliances are water-efficient and use recycled water. Low-impact materials were specified and these come from renewable or recycled sources within 35 miles of the site, to minimize embodied energy. This scheme incorporates collection facilities to support recycling. To encourage eco-friendly transport, electric and liquefied-petroleum-gas cars have 
priority over petrol and diesel cars and there are parking spaces for charging electric cars (Desai and Riddlestone 2002). All these design considerations mean people living in BedZED have a reduced ecological footprint (identified by BioRegional as 4.7 gha compared to the UK average of 5.5 gha) and this makes the project somewhat more sustainable (BioRegional 2009). Another very important aspect of BedZED is the fact that it also strongly promotes behaviour and lifestyle changes such as joining the car club which reduces the carbon emissions of occupants' whole lifestyle by $50 \%$ (BioRegional 2009). Encouraging behavioural change through governance and estate management, make BedZED one of the earlier eco-villages that is beginning to identify the importance of behaviour. However, communal elements like the CHP plant and "Living Machine" system to treat waste water have failed whereas those at a household scale (PV, gardens, passive solar, water) have worked (BioRegional 2009).

\section{Case study Six: Govardhan Eco Village, India (2003)}

Govardhan Eco Village aims for "Simple living and High thinking", and demonstrates practical ways of achieving a sustainable lifestyle. The scheme revolves around 5 elements (Govardhan 2014);

1. Natural Buildings

2. Sewage Treatment

3. Organic Farming

4. Alternative energy from solar energy and biogass

5. Education for sustainable behaviour

Govardhan Eco Village is a farm community spread over 60 acres at Galtare, Wada, $110 \mathrm{~km}$ North of Mumbai that incorporates use of alternative energy, eco friendly construction, and sustainable living. Alternative energy sources such as biogas and PV panels reduce dependency on the national grid (GEV 2013). The green building scheme considers existing ecologies, ensuring the constructional choices do not impact the surrounding site negatively. This is achieved by having separate building and planting zones. Use of materials 90\% sourced from within a 100 kilometre radius (GEV 2013b), coupled with zoned construction, hinder unsustainable behaviour by limiting material choices possible in the built architecture. There is also a waste management system, linked with biogas generation on site, and water harvesting (GEV 2013c). Finally organic farming is the sole source of food making this project, like Fuji Eco-park in Japan, self-sufficient in food. As shown in table 1, most if not all the parameters for Goverdhan Eco Village focus on the behaviour and impact of the occupants, with less reliance on innovative technologies for generating energy. Everything from choices made during construction to the way occupants eat and sources of food are governed by local resources.

\section{FINDINGS}

Table 2: Parameters based on Agenda 21 sustainability indicators in date order

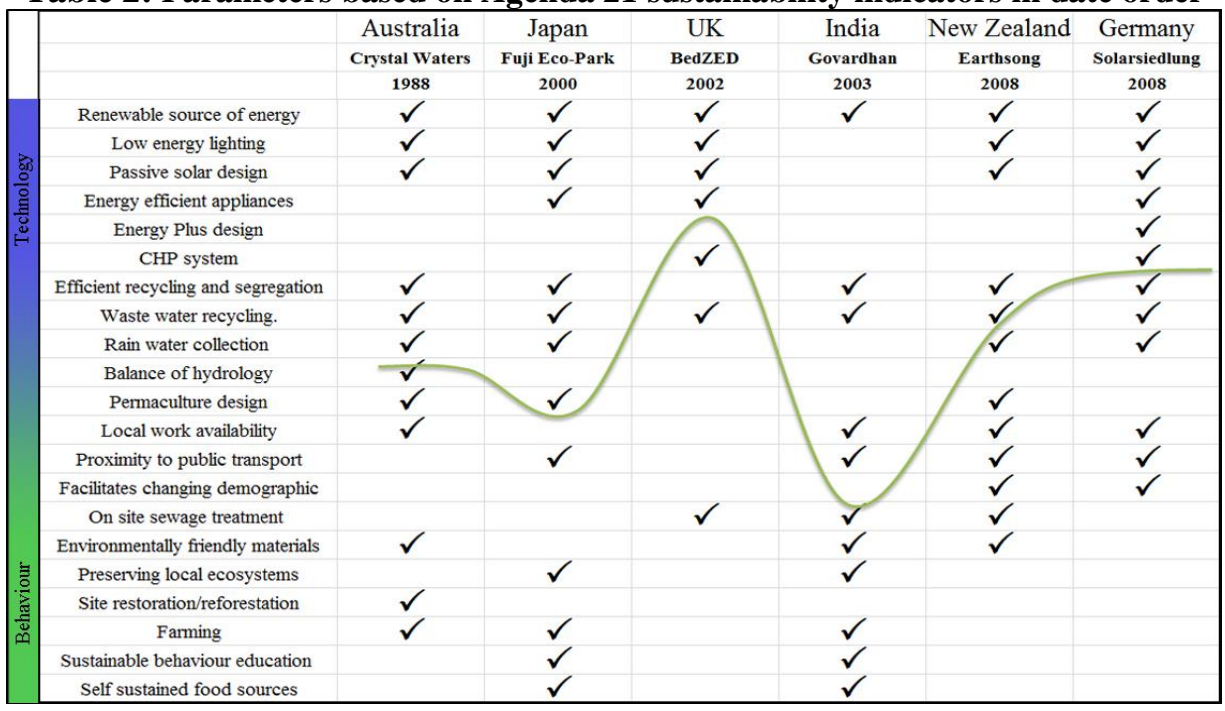


In Table 2 the order of the parameters has been changed to place those parameters that can be considered 'technology based' towards the top and those that can be considered 'behaviour based' towards the bottom. The trend line in table 2, which follows the mid-point of the parameters in each case study shows that no obvious change based trends in the parameters are observable over time. This suggests the focus on technology versus behaviour is arbitrary.

In the next step (Tables 3 and 4) the case studies were segregated and grouped. Grouping the 'eastern' case studies (Japan and India) seperately from the 'western' case studies (England, Germany, Australia and New Zealand) created two distinct trends, showing a definite shift in focus.

Table 3: Eastern Model

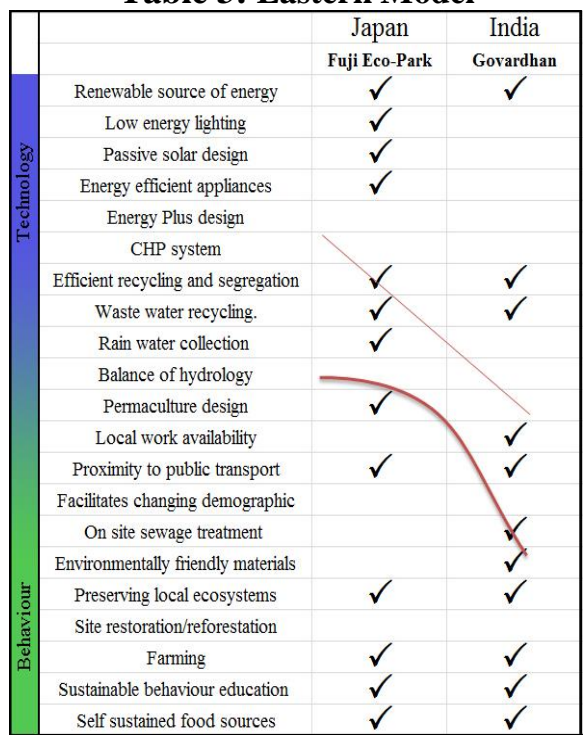

Table 4: Western Model

\begin{tabular}{|c|c|c|c|c|c|}
\hline & & Australia & $\mathrm{UK}$ & New Zealand & Germany \\
\hline & & Crystal Waters & BedZED & Earthsong & Solarsiedlung \\
\hline & Renewable source of energy & $\checkmark$ & $\checkmark$ & $\checkmark$ & $\checkmark$ \\
\hline & Low energy lighting & $\checkmark$ & $\checkmark$ & $\checkmark$ & $\checkmark$ \\
\hline & Passive solar design & $\checkmark$ & $\checkmark$ & $\checkmark$ & $\checkmark$ \\
\hline & Energy efficient appliances & & $\checkmark$ & & $\checkmark$ \\
\hline & Energy Plus design & & & & \\
\hline & CHP system & & & & \\
\hline & Efficient recycling and segregation & $\checkmark$ & & & $\checkmark$ \\
\hline & Waste water recycling. & $\checkmark$ & & & $\checkmark$ \\
\hline & Rain water collection & $\checkmark$ & & & $\checkmark$ \\
\hline & Balance of hydrology & 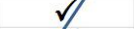 & & & \\
\hline & Permaculture design & $W$ & & & \\
\hline & Local work availability & $\checkmark$ & & $\checkmark$ & $\checkmark$ \\
\hline & Proximity to public transport & & & $\checkmark$ & $\checkmark$ \\
\hline & Facilitates changing demographic & & & $\checkmark$ & $\checkmark$ \\
\hline & On site sewage treatment & & & $\checkmark$ & \\
\hline & Environmentally friendly materials & $\sqrt{ }$ & & $\checkmark$ & \\
\hline 言 & Preserving local ecosystems & $\checkmark$ & & & \\
\hline$\sum_{0}^{2}$ & Site restoration/reforestation & $\checkmark$ & & & \\
\hline & Farming & $\checkmark$ & & & \\
\hline & Sustainable behaviour education & $\checkmark$ & & & \\
\hline & Self sustained food sources & & & & \\
\hline
\end{tabular}

In Table 3, the Eastern Model, there is a shift over time towards incorporating more parameters for sustainable behaviour, education and food self-sufficiency. The Western Model (Table 4) shows an increasing reliance on technology. Crystal Waters is most similar to the eastern models and also one of the oldest western case studies (26 years old). Like the former it is self-sufficient in food but unlike the eastern case studies (and the other western ones) it does not have good access to public transport and other local facilities, suggesting sustainable settlement design in the west might only follow the eastern model if the site is rural and remote. This also suggests that the differences may be to do with having a suburban rather than a rural location. However, this would require further research and an extended list of case studies, as well as more detailed studies of measured performance. The trends depicted in the findings of this paper are established through a very small sample, especially for the eastern set. In addition, it would be worth carrying out much more detailed studies to see the measurable degree of sustainability offered by each settlement, perhaps using ecological footprint, as for BedZED, the only one of the six which is relatively fully documented or per capita energy consumption.

\section{CONCLUSION}

This research shows that most (if not all) the case studies appear to consider themselves in alignment with Agenda 21. However this 'tick the boxes' approach to assessment does not highlight a more fundamental difference in the approach to sustainable development as shown by the Eastern and Western Models. The former, with less reliance on technology and more on human capital, could be viewed as more sustainable than the Western Model. It has been shown by other research that significantly greater reductions in ecological footprint and therefore increased sustainability can be achieved by behavioural change than by technology (Vale and Vale, 2013). Further detailed investigation of ecological footprint and other measured aspects of performance in use, such as per capita energy demand, would show if this is indeed the case.

Given the state of the world, it is perhaps the case study from India that is showing the way to true 
sustainable development, especially for developing countries, with the focus on sustainable education, behaviour and food self-sufficiency. As BedZED shows, reliance on 'innovative' technology can be misplaced, whereas where the community is responsible for its own food and dealing with its own wastes, based on human capital, there is less chance of failure.

\section{REFERENCES}

Bakshi, N. (2009). Our Sustainable Side. School of Architecture. Victoria University of Wellington. NZ.

Bell, S., \& Morse, S. (2008). Sustainability indicators: Measuring the immeasurable?. London: Earthscan.

BioRegional (2009). BedZED seven years later. http://www.bioregional.com/files/publications/bedzedseven-years-exec-summary.pdf Retrieved 24 May 2014

Barton, H. (2000). Sustainable communities: The potential for eco-neighbourhoods. London: Earthscan.

Behling, S., \& Schindler, B. (1996). Sol power: The evolution of solar architecture. Munich: Prestel.

CARBSE (2014). Center for Advanced Research in Building Science \& Energy (CARBSE). http://cept.ac.in/179/center-for-advanced-research-in-building-science-energy-carbse- Retrieved 24 May 2014

Desai, P., \& Riddlestone, S. (2002). Bioregional solutions for living on one planet. Totnes, Devon: Green Books for the Schumacher Society.

EEG. (2000). Renewable Energy Sources Act. http://www.erneuerbare-energien.de/en/topics/acts-andordinances/renewable-energy-sources-act/eeg-2012/ Retrieved 05 June 2014

Earthsong Eco-neighbourhood. (1999). Earthsong Database resource section: Design Brief. http://www.earthsong.org.nz/docs/DesignBrief.pdf. Retrieved 24 May 2014

Earthsong Eco-neighbourhood. (2014). Earthsong Information section: About Earthsong. http://www.earthsong.org.nz/about.html Retrieved 24 May 2014

Ewing B. \& Moore D. (2014). Ecological Footprint Atlas 2010, Oakland CA: Global Footprint Network.

Fujieco. (2014). Fuji Eco-park home page. http://www.fujieco.co.jp/ Retrieved 24 May 2014

Global footprint network. (2010). Ecological footprint atlas. Retrieved 05 June 2014.

http://www.footprintnetwork.org/en/index.php/GFN/page/ecological_footprint_atlas_2010

GEN. (2014). How Sustainable is Your Community? Community Sustainability Assessment. Global Ecovillage Network. Retrieved 25 May 2014

GEV. (2013). Alternative energy. http://ecovillage.org.in/Case-Studies/Alternative\%20energy.pdf Retrieved 24 May 2014

GEV. (2013b). Green Building Technology. http://ecovillage.org.in/CaseStudies/Green\%20Building\%20Technology.pdf Retrieved 24 May 2014

GEV. (2013c). Waste Management. http://ecovillage.org.in/Case-Studies/Waste\%20Management.pdf Retrieved 24 May 2014

Gore, A. 2006. 'An Inconvenient Truth'. Pennsylvania: Rodale Press.

Global Footprint Network. 2009. Ecological Footprint Standards 2009. In J. Kitzes (Ed.). Oakland, CA.

Govardhan 2014. Govardhan Eco Village website. http://www.ecovillage.org.in/ Retrieved 24 May 2014

Holling, C.S. 2000 'Theories for sustainable futures'. Conservation Ecology, 4.

Kachadorian, J. (1997). The passive solar house. White River Junction, Vt: Chelsea Green Pub. Co.

Mollison, B. C., \& Slay, R. M. (1994). Introduction to permaculture. Tyalgum, Australia: Tagari Publications.

Permaculture news. (2014). Permaculture Research institute of Australia. http://permaculturenews.org/ Retrieved 24 May 2014

Solar Architecture. (2014). The Solar Settlement in Freiburg. http://www.rolfdisch.de Retrieved 24 May 2014

United Nations General Assembly. (1987). 'Report of the world commission on environment and development: Our common future, chapter 2: Towards sustainable development'.

United Nations Environment Programme. (1992). Agenda 21 - 10.1 Integrated Approach to the Planning and Management of Land Resources.: United Nations http://www.unep.org/Documents.Multilingual/Default.asp?DocumentID=52\&ArticleID=58. Retrieved 24 May 2014

Vale R. and Vale B. (eds) (2013) Living within a fair share ecological footprint. Abingdon, Oxon: Routledge.

Vale R. (2014). Personal communication September 2, 2014.

World Permaculture projects (WPP) (2014) Japan - Fuji Eco-Park Village http://www.permacultures.com/wp/2010/05/22/japan-fuji-eco-park-village/ Retrieved 24 May 2014

WWF 2010. Living Planet Report 2010. Gland, Switzerland: World Wide Fund for Nature. 